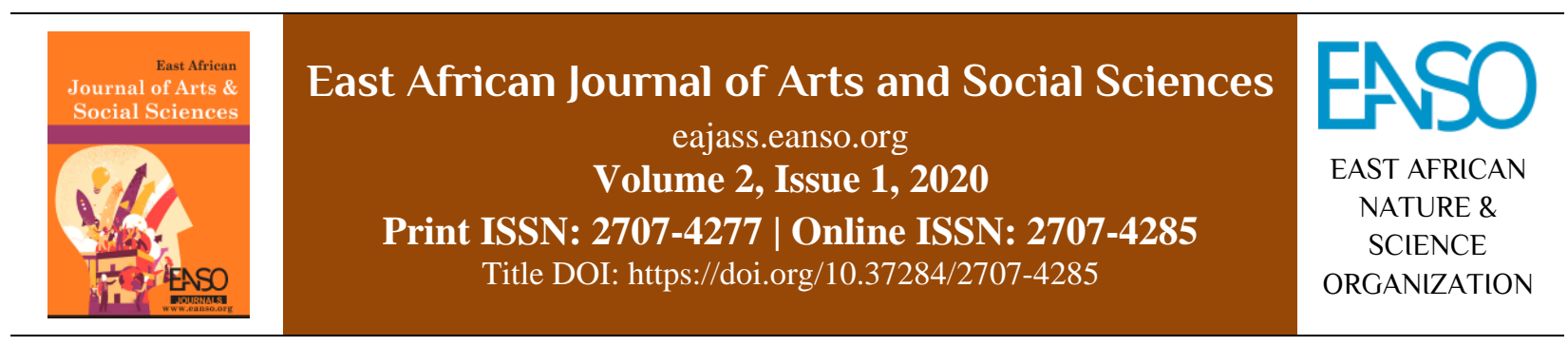

Original Article

\title{
Testing Citizen Satisfaction in the Local Government: Focusing on the Vision 2020 Umurenge Program in Rwanda
}

\author{
Pierre Celestin Bimenyimana ${ }^{1}$ \& Prof. Moon-Gi Jeong, PhD ${ }^{l}$ \\ ${ }^{1}$ Department of Public Administration, Graduate School of Governance-Sungkyunkwan University 25-2, Sungkyunkwan-ro, \\ Jongno-gu, Seoul-Republic of Korea. \\ *Author for Correspondence email: bipiece@gmail.com \\ *ORCID: https://orcid.org/0000-0003-4303-8087
}

Article DOI: https://doi.org/10.37284/eajass.2.1.166

\section{Article history: ABSTRACT}

12 June 2020 Public administration scholars and practitioners need to understand how citizens form judgments regarding programs implemented at the local government level.

Keywords: The expectancy disconfirmation model of citizen satisfaction (EDM) focuses on comparing performance and expectations and was found important to

$E D M$, understand that. This study tests the application of the expectancy

Citizen Participation, Citizen Satisfaction,

Local Government,

Vision 2020,

Umurenge Program. disconfirmation model of citizen satisfaction in the local government of Rwanda focusing on the Vision 2020 Umurenge Program (VUP), which is a flagship of the social protection programs in Rwanda since 2008. It predicts that satisfaction with the program may increase the level of citizen participation. Data was collected from 379 VUP beneficiaries of the program in the Gicumbi district of Rwanda using an online survey questionnaire. We applied the Structural Equation Model and correlation analysis to analyze the data. The results found EDM applicable to how citizen forms a judgment about satisfaction with VUP where there is a positive relationship between expectations and actual performance of the program (positive disconfirmation) and positive influence of EDM with VUP to citizen participation. The study suggests that the governments should take into consideration the citizens' feedback so as to meet their expectations and their satisfaction which may increase the level of citizen participation.

\section{APA CITATION}

Bimenyimana, P., \& Jeong, M. (2020). Testing Citizen Satisfaction in the Local Government: Focusing on the Vision 2020 Umurenge Program in Rwanda. East African Journal of Arts and Social Sciences, 2(1), 33-47. https://doi.org/10.37284/eajass.2.1.166 


\section{CHICAGO CITATION}

Bimenyimana, Pierre, and Moon-Gi Jeong. 2020. "Testing Citizen Satisfaction in the Local Government: Focusing on the Vision 2020 Umurenge Program in Rwanda”. East African Journal of Arts and Social Sciences 2 (1), 33-47. https://doi.org/10.37284/eajass.2.1.166.

\section{HARVARD CITATION}

Bimenyimana, P. and Jeong, M. (2020) "Testing Citizen Satisfaction in the Local Government: Focusing on the Vision 2020 Umurenge Program in Rwanda”, East African Journal of Arts and Social Sciences, 2(1), pp. 33-47. doi: 10.37284/eajass.2.1.166.

\section{IEEE CITATION}

P. Bimenyimana and M. Jeong, "Testing Citizen Satisfaction in the Local Government: Focusing on the Vision 2020 Umurenge Program in Rwanda", EAJASS, vol. 2, no. 1, pp. 33-47, Jun 2020.

\section{MLA CITATION}

Bimenyimana, Pierre, and Moon-Gi Jeong. "Testing Citizen Satisfaction in the Local Government: Focusing on the Vision 2020 Umurenge Program in Rwanda". East African Journal of Arts and Social Sciences, Vol. 2, no. 1, Jun 2020, pp. 33-47, doi:10.37284/eajass.2.1.166.

\section{INTRODUCTION}

It is very important for public administration scholars and practitioners to understand how citizens form judgments regarding programs implemented at the local government level. The expectancy disconfirmation model of citizen satisfaction (EDM) deals with the expectations in comparison with performance (Van Ryzin, 2005). This study tests the application of the expectancy disconfirmation model of citizen satisfaction in the local government of Rwanda focusing on the Vision 2020 Umurenge Program (VUP). The program is a flagship of the social protection in Rwanda since 2008 and suggesting that satisfaction from the program may increase the level of citizen participation.

Different reports have been released on citizen satisfaction in Rwanda but these reports need to include expectations and disconfirmation compared to the program performance. In other words, the reports have reported the program performance but need to understand expectations and disconfirmation from citizens benefiting from the program. Citizen satisfaction can be determined by a combination of expectations, disconfirmation, and performance. A number of studies were done on citizen satisfaction and have shown that overall satisfaction can be determined by various factors (Van Ryzin et al., 2004; Van Ryzin, 2004; Greasley
\& John, 2011). Citizen satisfaction with government services is a result of both public expectations and perception of government performance.

This study aims at testing the Expectancy Disconfirmation Model (EDM) of citizen satisfaction with the Vision 2020 Umurenge Program (VUP) implemented in the local government of Rwanda. This will be achieved by investigating how the citizen forms their judgments about the satisfaction with the program by the local governments of Rwanda; we have also investigated the relationship with the model applied to VUP with citizen participation. Rwanda has been undergoing different phases of decentralization since 2000 believing that bringing service provision near to the users will increase their level of participation. The Rwanda Governance Board has done various reports on citizen satisfaction in Rwanda and the reports have shown that citizen satisfaction increases year after year but we found it crucial to investigate the factors behind this citizen satisfaction (RGB, 2016).

Rwanda's main national social protection program is the VUP, run by MINALOC. Only households 
classified as Ubudehe categories $1^{1}$ are eligible to be beneficiaries. The Rwandan Vision 2020 Umurenge Program (VUP) was established in 2008 under the Ministry of Local Government, currently implemented within the Local Administrative Entities Development Agency (LODA). This program is in relation to the National Constitution, Articles $14 \& 28$ are the driving force for the longterm vision for social protection and goes along with sustainable development goals.

VUP aims at making a critical contribution to Rwanda's efforts to eradicate extreme poverty, malnutrition and promotes socio-economic transformation by accelerating graduation from extreme poverty and strengthening household resilience and it is being implemented through its three main components (LODA, 2016): Direct Support - unconditional monthly income support (cash transfer) for the extremely poor, severely labour-constrained household; Public Work - shortterm employment on labour-intensive Public Works for labour-endowed \& poor households; and Financial Services - which consist of micro-credit, financial education and coaching, and access to insurance to poor households which may have a small income project idea;

In this paper, the research has found it of a very crucial role to investigate how citizens form their overall satisfaction with Vision 2020 Umurenge Program which has been implemented from 2008 by the local governments of Rwanda by utilizing the expectancy disconfirmation model of satisfaction (EDM) and testing the contribution of this satisfaction to citizen participation.

This research is using the Expectancy disconfirmation theory to test citizen satisfaction with the Vision 2020 Umurenge Program and the contribution of overall citizen satisfaction with

\footnotetext{
${ }^{1}$ In ubudehe categorization of Rwanda people are put in 4 categories following their economic status; such categories are in short:

Category one: very poor without house, unable to get food

Category two: own house, casual works and get food with difficult
}

VUP and citizen participation in Rwanda. This theory (EDT) holds that citizens or consumers form their satisfaction basing on their prior expectations about the service or the product heard via publicity. For example, Oliver (1980) points out that after experiencing the service or product these expectations now serve as a comparison between the prior expectations and actual performance to form judgments about satisfaction. The gap between citizen expectations and actual performance of the service or product is referred to as "expectancy disconfirmation" (Erevelles \& Leavitt 1992; Oliver, 1997); it is very crucial to note that this gap can be positive as well as negative. It is positive when actual performance exceeds expectations (positive disconfirmation). It is negative when actual performance falls short of expectations (negative disconfirmations). A prior study by Van Ryzin (2004) empirically supports the expectancy disconfirmation model as a description of how citizens form their overall satisfaction with the local government services.

\section{LITERATURE REVIEW}

\section{Citizen Satisfaction}

The citizen satisfaction can be determined by analyzing how people perceive different sections of their governments and of course we should investigate the reasons behind these people's perceptions. For example, if people are reporting that they are satisfied at a given level, it is crucial to understand the factors behind the level of citizen satisfaction. An individual's satisfaction with a government can be seen as based on his or her assessment or evaluation of the different parts of that government (Campbell, 1981). From this perspective, this survey will be evaluation expectations of the VUP beneficiaries and then have a look at the program performance which may

Category three: at least one person working at the middle \& lower level, agriculture for market.

Category four: senior workers (directors) big business 
be combined with disconfirmation and give satisfaction.

There is a relationship between citizen satisfaction and citizen expectation and there is a positive relationship between citizen satisfaction and citizen perception of government performance (Putnam, 2000). Good governance is characterized by institutions and process which encourages citizens to be participative so as to ensure representation in the government, transparency in all, and people to be accountable for their deeds, for the effectiveness of the government and the quality of public service provided (Protik et al., 2018).

\section{Citizen Participation}

Citizen participation does not have one agreedupon definition. Some of the observers generally consider citizen participation increasing as a way to connect the public to the government and allow the public to play a considerable role in shaping their society (Ongaro et al., 2011). Citizen participation must be real, engaging people, and willingly for everyone to exercise his own judgment and initiative (Pitkin, 1999). Citizen participation is the mobilization of citizens for the purpose of undertaking activities to improve conditions in the community (DiClemente, Crosby \& Kegler, 2009). To some people, citizen participation is understood as having a relationship with human agency in the political area, in a general sense, it is defined as citizenship "as rights that enable people to exercise their agency as citizens" (Amenta, Caren, \& Stobaugh, 2012).

Citizenship actions put together the acts of voting and paying taxes, and in some cases, they give the contestation over the definition of citizenship. They disturb or bring problems previously existing in societal codes of conduct changing how citizenship is understood such as the use of rights by protesting and collective mobilization (McGarry, 2017).

The previous research results have shown that citizen participation is minimal compared to different forms of citizen participation outlined in the USA acts of citizen participation, portals have shown moderate information concerning of participatory budgeting and an incipient use of the empty chair (Henríquez-Coronel et al., 2018). Citizen participation includes legal citizenship, participation in the electoral process, and participation in more informal political acts such as petition-signing campaigns, demonstrations, and forms of organizational life. It also includes immigrants 'direct participation in political institutions through both ethnic (or demographic) representation which refers to a type of representation in which the characteristics of legislators proportionately reflect those of the population. The policy representations refer to the adoption and implementation of public policies that reflect their needs and interests (Barkan, 2013).

\section{Expectancy Disconfirmation Model}

It is of a big importance for public administration scholars and practitioners to understand how citizens form judgments regarding programs implemented at the local government level. Expectancy disconfirmation theory focuses on the gap between expectations and actual performance of a product or a service. This model has been tested in previous decades especially in relation to customer satisfaction in the private sector, yet it is still little known in the field of public administration (Van Ryzin, 2004). From the above point of view, it is understandable that before consuming a product or a service, there is the level of satisfaction that the customer is expecting to get from it which is referred to as expectations. After using the product or service, there is a level of satisfaction that the user has got from that product or service that is what is referred to as actual performance. The gap between the prior expectations and actual performance is known as expectancy disconfirmation. In this context, the disconfirmation of expectations can be positive as it can be also negative, it is positive when the actual performance has exceeded prior expectations and it 
is negative when the actual performance falls short of expectations.

According to Oliver (1980); expectations are defined as consumers' or citizen's prior predictions or anticipations from prior experience about the product or service and this prior experience can be perceived through advertisements of that service or product via media. The same author defines actual performance as a consumer's or citizen's evaluation of the product or the service basing on recent consumption of that product or service.

According to Rwanda Governance Board (2013), in its Citizen Report Card 2013, the public service delivery at the local level are somehow satisfying whereby the population perceptions showed the net dissatisfaction at $9 \%$ and the net satisfaction at $60 \%$, the majority of the population perceives services from the local government as good followed by those who think it is average, with $31.5 \%$. The same report in the following years, as it will be discussed later in detail, has shown an increase in citizen satisfaction on the public service at the local levels in Rwanda.

\section{MODEL AND HYPOTHESIS}

The theory related to this study is the expectancy disconfirmation theory of citizen satisfaction. Expectancy disconfirmation theory is relevant for research about government services targeting the public as well as the management of the public and practice. This is relevant to the current study which is using EDM to test a government program. Figure 1 presents the expectancy disconfirmation of citizen satisfaction with the citizen participation model.

Figure 1: Expectancy Disconfirmation of Citizen Satisfaction with Citizen Participation Model

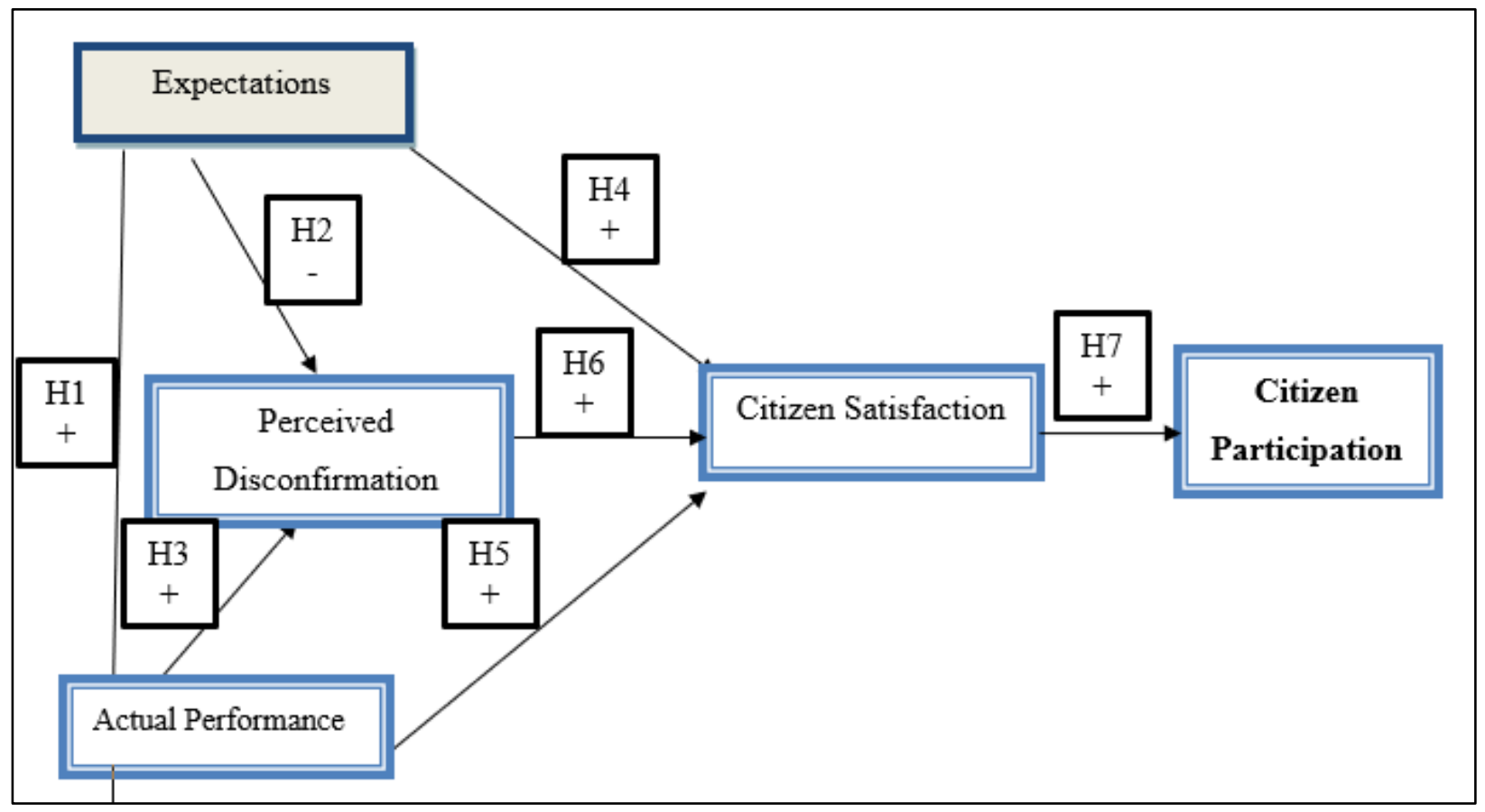

Recent research has focused on positive outcome expectations (or affirmatively worded values); however, it is also important to assess negative outcome expectations (Scheier \& Carver 1985). This relationship was confirmed by previous studies such as by Van Ryzin (2005). There is a relationship between expectations with disconfirmation of these expectations, where it states a negative influence of expectations on disconfirmation. Expectations can be high, average 
or low; those with high expectations will result in having a high percentage of experiencing negative disconfirmations while those with low expectations are likely to have a high chance of positive disconfirmation and those with average expectations are likely to have their expectations confirmed.

H1: Expectations have a positive relationship with Actual Performance

H2: Expectations have a negative relationship with Disconfirmation

Hypothesis 3 states the relationship between actual performance and disconfirmation; the expectancy disconfirmation model hypothesizes that actual performance positively affects the disconfirmation of expectations. This suggests that high actual performance results in positive disconfirmation of expectations whereas low actual performance results in negative disconfirmation of expectations. In hypothesis 4, the relationship between expectations and citizen satisfaction is stated, the expectancy disconfirmation model of citizen satisfaction hypothesizes that when prior expectations are high, high satisfaction will come. However, this relationship is less intuitive (Van Ryzin, 2013),

H3: Performance has a positive relationship with Disconfirmation

H4: Expectations have a positive relationship with Citizen Satisfaction

This relationship was confirmed by previous studies (Wu et al., 2016).

Hypothesis 6 talks about the relationship between disconfirmation and citizen satisfaction, the expectancy disconfirmation model hypothesize that positive disconfirmation of expectations or high expectations is likely to result in high satisfaction, this also applies when the disconfirmation of expectations is negative meaning that negative disconfirmation is likely to result in lower satisfaction.

The high level of citizen participation is positively associated with citizen satisfaction, but the relationship between participation and satisfaction is significantly mediated by perceived public performance. More importantly, the positive relationship between citizen participation and satisfaction is mediated by the perceived assessment of respondents on the public performance of municipal services. (Wu et al., 2016).

H5: Performance has a positive relationship with Citizen Satisfaction

H6: Disconfirmation has a positive relationship with Satisfaction

H7: Expectancy Disconfirmation Model of citizen satisfaction with VUP has a positive relationship with Citizen Participation.

\section{DATA AND METHOD}

The population of this study was the beneficiaries of the Vision 2020 Umurenge Program in the Gicumbi District of Rwanda. According to the District Social Protection report of June 2018, the beneficiaries were 15,296 in total meaning 4,923 beneficiaries enrolled in direct support component; 6,000 enrolled in public works component and 4373 beneficiaries enrolled in financial services. With a confidence level set at $95 \%$; the sample size of this research should go at least to 375 respondents. We have followed a snowballing sampling technique in finding our respondents.

This research followed a survey format whereby the researcher collected people's perceptions of how citizens form their satisfaction with the Vision 2020 Umurenge Program implemented in the local government. The questionnaire for data collection was shared via online (WhatsApp and mails) by using google docs 
This research has followed a Structural Equation Model (SEM) and correlation analysis, whereby they were four independent variables grouped in Expectancy Disconfirmation Model (EDM) which are being investigated as determinants of citizen participation (which is described as the dependent variable of this research) with vision 2020 Umurenge Program in the local governments of Rwanda. Structural Equation Model has various advantages and these include that it can evaluate the relationship between endogenous and exogenous variables and accomplish these things (mechanism, direct and indirect relationships, reciprocal and multiple relationships) (Morgan, 2013).

Basing on the above-mentioned advantages, this survey has followed a structural equation model (SEM), whereby there will four independent variables grouped in one Expectancy disconfirmation model investigated as determinants of citizen participation (which is described as the dependent variable of this survey) which investigates how citizens form their satisfaction with Vision 2020 Umurenge Program in the local governments of Rwanda (Model 1). Each of the independent variables was measured by a number of questions. From these questions, the SPSS AMOS program was used to determine the relationship between the endogenous variables and exogenous variables composing the model.

\section{ANALYSIS AND FINDINGS}

The online survey questionnaire (using google forms) was administered to a sample size of 379 respondents, beneficiaries of the Vision 2020 Umurenge Program. All of the survey participants were beneficiaries of the said program from the Gicumbi District in the Northern Province of Rwanda.

In this study, as it is presented in Table 2, 54.1\% (208 respondents) of the respondents composed of females while $44.1 \%$ (167) were male while $1.1 \%$ (4 respondents) did not specify their gender. Out of the 279 respondents, $3.2 \%$ (12) were under the age of $21,33.2 \%$ (126) were aged 21-35 years while the majority $63.6 \%$ (241) were aged above 35 years. Most of the respondents did not acquire formal education $51.5 \%$ (195); those with primary education or 6 years basic education was $41.2 \%$ (156), 5.3\% (20) had high school education while only $2.1 \%$ (8) of the total sample have professional training. This shows that respondents the big percentages of the beneficiaries of the Vision 2020 Umurenge Program in Rwanda have no education.

The sample reflects that $90.5 \%$ (343) of the total number of respondents is unemployed, $4.2 \%$ (16) are entrepreneurs, $3.4 \%$ (13) are farmers while $1.8 \%$ (7) are students. In terms of length of in benefiting from the program, most of the respondents or $53.3 \%$ (202) have been benefiting from the program for less than 3 years; $44.1 \%$ (167) for 3 to 6 years; $1.8 \%$ for 6 to 9 year and $0.8 \%$ for more than 9 years. A considerable number of respondents are in the direct support component of the program which counts $63.9 \%$ (242); $22.2 \%$ (84) is in public works components of the program and only $14 \%$ (53) are in the financial services component of the program.

About the respondent's monthly income level, $\operatorname{most}(79.2 \%$ or 300 people) earned less than 30,000 Rwandan francs; $16.1 \%$ (61) earned between 30,001 and 50,$000 ; 2.1 \%$ (8) earned 50,001 to 70,000 Rwandan francs; the ones who have the monthly income ranging from 70,001 to 90,000 Rwandan francs counts $1.6 \%$ (6) while four respondent earned above 90,000. About the location of the respondents, they are from all of the 21 administrative sectors composing Gicumbi District whereby Kaniga Sector has the biggest number of respondents followed by Rubaya Sector while the Cyumba sector had the lowest number of respondents proceeded by Mutete sector. Table 1 summarized the demographic characteristics of the sample. 
Table 1: Demographic Characteristics of the Respondents

\begin{tabular}{|c|c|c|c|c|c|c|c|}
\hline Contents & Dimensions & f & $\%$ & Contents & Dimensions & $\mathbf{f}$ & $\%$ \\
\hline VUP_B & Yes & 379 & 100 & M_Income & $\leq 30,000$ & 300 & 79.2 \\
\hline \multirow[t]{4}{*}{ Gender } & Male & 167 & 44.1 & & $30,001-50,000$ & 61 & 16.1 \\
\hline & Female & 208 & 54.9 & & $50,001-70000$ & 8 & 2.1 \\
\hline & Prefer not to Say & 4 & 1.1 & & $70,001-90,000$ & 6 & 1.6 \\
\hline & Total & 379 & 100 & & Over 90,000 & 4 & 1.1 \\
\hline \multirow[t]{4}{*}{ Age } & $<21$ years & 12 & 3.2 & & Total & 379 & 100 \\
\hline & 21 - 35 years & 126 & 33.2 & Location & Bukure & 6 & 1.6 \\
\hline & $>35$ years & 241 & 63.6 & & Bwisige & 24 & 6.3 \\
\hline & Total & 379 & 100 & & Byumba & 17 & 4.5 \\
\hline \multirow[t]{5}{*}{ Education } & None education & 195 & 51.5 & & Cyumba & 4 & 1.1 \\
\hline & Primary education & 156 & 41.2 & & Giti & 6 & 1.6 \\
\hline & High school Level & 20 & 5.3 & & Kageyo & 20 & 5.3 \\
\hline & Professional Training & 8 & 2.1 & & Kaniga & 69 & 18.2 \\
\hline & Total & 379 & 100 & & Manyagiro & 20 & 5.3 \\
\hline \multirow[t]{5}{*}{ Occupation } & Unemployed & 343 & 90.5 & & Miyove & 22 & 5.8 \\
\hline & Entrepreneur & 16 & 4.2 & & Mukarange & 11 & 2.9 \\
\hline & Farmer & 13 & 3.4 & & Muko & 21 & 5.5 \\
\hline & Student & 7 & 1.8 & & Mutete & 5 & 1.3 \\
\hline & Total & 379 & 100 & & Nyamiyaga & 7 & 1.8 \\
\hline \multirow[t]{4}{*}{ Component } & Direct Support (DS) & 242 & 63.9 & & Nyankenke & 11 & 2.9 \\
\hline & Public Works (PW) & 84 & 22.2 & & Rubaya & 29 & 7.7 \\
\hline & Financial Services & 53 & 14 & & Rukomo & 14 & 3.7 \\
\hline & Total & 379 & 100 & & Rushaki & 22 & 5.8 \\
\hline Years with & $\leq 3$ years & 202 & 53.3 & & Rutare & 11 & 2.9 \\
\hline \multirow[t]{4}{*}{ VUP } & 3 - 6 years & 167 & 44.1 & & Ruvune & 20 & 5.3 \\
\hline & $6-9$ years & 7 & 1.8 & & Rwamiko & 16 & 4.2 \\
\hline & Above 9 years & 3 & 0.8 & & Shangasha & 24 & 6.3 \\
\hline & Total & 379 & 100 & & Total & 379 & 100 \\
\hline
\end{tabular}

About the items used in this survey, they are 21 in total which comprises 9 demographic questions as discussed in the above table and 12 questions relating to the variables composing the survey model Table 2 gives the details about the items used concerning the model variables. 
Table 2: Question-wording and descriptive statistics for the model variables

\begin{tabular}{|c|c|c|c|c|c|}
\hline Variable & Survey item(s) & Min. & Max. & Mean & $\begin{array}{l}\text { Std. } \\
\text { Dev. }\end{array}$ \\
\hline \multirow{3}{*}{ Expectations } & $\begin{array}{l}\text { Thinking back a few years, how do you rate your } \\
\text { expectations from Direct Support? }\end{array}$ & 1 & 7 & 4.99 & 2.02 \\
\hline & $\begin{array}{l}\text { Thinking back a few years, how do you rate your } \\
\text { expectations from Public Works? }\end{array}$ & 1 & 7 & 5.15 & 1.99 \\
\hline & $\begin{array}{l}\text { Thinking back a few years, how do you rate your } \\
\text { expectations from Financial Services? }\end{array}$ & 1 & 7 & 5.05 & 1.93 \\
\hline \multirow{3}{*}{$\begin{array}{l}\text { Actual } \\
\text { Performance }\end{array}$} & $\begin{array}{l}\text { Now, think about today, how would you rate what } \\
\text { you have benefited from Direct Support? }\end{array}$ & 1 & 4 & 2.81 & 0.85 \\
\hline & $\begin{array}{l}\text { Now, think about today, how would you rate what } \\
\text { you have benefited from Public Works? }\end{array}$ & 1 & 4 & 2.71 & 0.88 \\
\hline & $\begin{array}{l}\text { Now, think about today, how would you rate what } \\
\text { you have benefited from Financial Services? }\end{array}$ & 1 & 4 & 2.64 & 0.89 \\
\hline $\begin{array}{l}\text { Perceived } \\
\text { Disconfirmation }\end{array}$ & $\begin{array}{l}\text { Considering all of your EXPECTATIONS, to what } \\
\text { extent have the benefits you got from VUP fallen } \\
\text { short of your expectations or exceeded your } \\
\text { expectations? }\end{array}$ & 1 & 7 & 4.87 & 1.86 \\
\hline $\begin{array}{l}\text { Citizen } \\
\text { Satisfaction }\end{array}$ & $\begin{array}{l}\text { Overall, how SATISFIED are you with support } \\
\text { from VUP? }\end{array}$ & 1 & 7 & 5.09 & 1.79 \\
\hline \multirow{4}{*}{$\begin{array}{l}\text { Citizen } \\
\text { Participation }\end{array}$} & $\begin{array}{l}\text { Looking back in } 1 \text { year, how often have you } \\
\text { participated in local meeting or other community } \\
\text { activities }\end{array}$ & 1 & 3 & 2.44 & 0.58 \\
\hline & $\begin{array}{l}\text { After being involved in VUP, I feel like I can } \\
\text { change my world for the better through } \\
\text { participating in different local activities }\end{array}$ & 1 & 5 & 3.81 & 1.21 \\
\hline & $\begin{array}{l}\text { After being involved in VUP, I feel like "I can } \\
\text { make my community a better place by helping } \\
\text { others in need," }\end{array}$ & 1 & 5 & 3.73 & 1.24 \\
\hline & $\begin{array}{l}\text { After being involved in VUP, I feel like "There are } \\
\text { things I can do to make the world a better place" }\end{array}$ & 1 & 5 & 3.8 & 1.24 \\
\hline
\end{tabular}

The descriptive statistics provide that expectations from the Direct support component of the program have a mean value of $4.99($ Std. dev. = 2.016) compared with expectations from public works component of the program with the mean of 5.15 (Std. dev. $=.1 .986)$ while expectations from Financial services had a mean of 5.05 (Std. dev. = 1.926). The actual performance of Direct support components of VUP has the mean of 2.81 (Std. dev $=.850$ ) while the actual performance of public works component of VUP has the mean 2.71 (Std. $\mathrm{dev}=.878$ ) and the actual performance from financial services component of VUP has the mean values of 2.64 (Std. dev. $=.886)$. Disconfirmation of expectations has the mean value of 4.87 (Std. dev $=1.862$ ), the satisfaction with VUP has the mean 5.09 (Std. dev. $=1.790$ ) and the dependent variable which is citizen satisfaction has the mean value of 3.45 (Std. dev. = .9483).

All of the variables were found correlated significantly at the level of 0.01 (2-tailed) see Table 3. 
East African Journal of Arts and Social Sciences, Volume 2, Issue 1, 2020

Article DOI: https://doi.org/10.37284/eajass.2.1.166

Table 3: Bivariate Correlations of Variables (model 1)

\begin{tabular}{|c|c|c|c|c|c|c|c|c|c|}
\hline & $\mathbf{A}$ & $\mathbf{B}$ & $\mathbf{C}$ & D & $\mathbf{E}$ & $\mathbf{F}$ & $\mathbf{G}$ & $\mathbf{H}$ & I \\
\hline Expectations_DS (A) & 1 & & & & & & & & \\
\hline Expectations_PW (B) & $.618^{* *}$ & 1 & & & & & & & \\
\hline Expectations_FS ( C) & $.655^{* *}$ & $.888^{* *}$ & 1 & & & & & & \\
\hline AP_DS (D) & $.502^{* *}$ & $.312^{* *}$ & $.254^{* *}$ & 1 & & & & & \\
\hline AP_PW (E) & $.404^{* *}$ & $.566^{* *}$ & $.451^{* *}$ & $.540^{* *}$ & 1 & & & & \\
\hline AP_FS $(\mathrm{F})$ & $.315^{* *}$ & $.496^{* *}$ & $.525^{* *}$ & $.511^{* *}$ & $.731^{* *}$ & 1 & & & \\
\hline Disconfirmation $(\mathrm{G})$ & $.669^{* *}$ & $.555^{* *}$ & $.551^{* *}$ & $.618^{* *}$ & $.512^{* *}$ & $.486^{* *}$ & 1 & & \\
\hline Satisfaction_VUP $(\mathrm{H})$ & $.671^{* *}$ & $.632^{* *}$ & $.610^{* *}$ & $.611^{* *}$ & $.590^{* *}$ & $.518^{* *}$ & $.832^{* *}$ & 1 & \\
\hline Cit_Part (I) & $.594^{* *}$ & $.709^{* *}$ & $.661^{* *}$ & $.425^{* *}$ & $.512^{* *}$ & $.364^{* *}$ & $.652^{* *}$ & $.698^{* *}$ & 1 \\
\hline
\end{tabular}

**. In this data, Correlation is significant at the level of 0.01 (2-tailed).

In running the SEM in SPSS AMOS, we have used two models whereby model 1 investigates how people form their satisfaction with vision 2020 Umurenge Program in its different components. From this model, we have been able to determine the contribution of each component and the relationships between these components meaning that model 1 is expanded in the components of the program (Figure 2).

Figure 2: Vision 2020 Umurenge Program Expectancy-Disconfirmation model with Citizen Participation (Model 1)

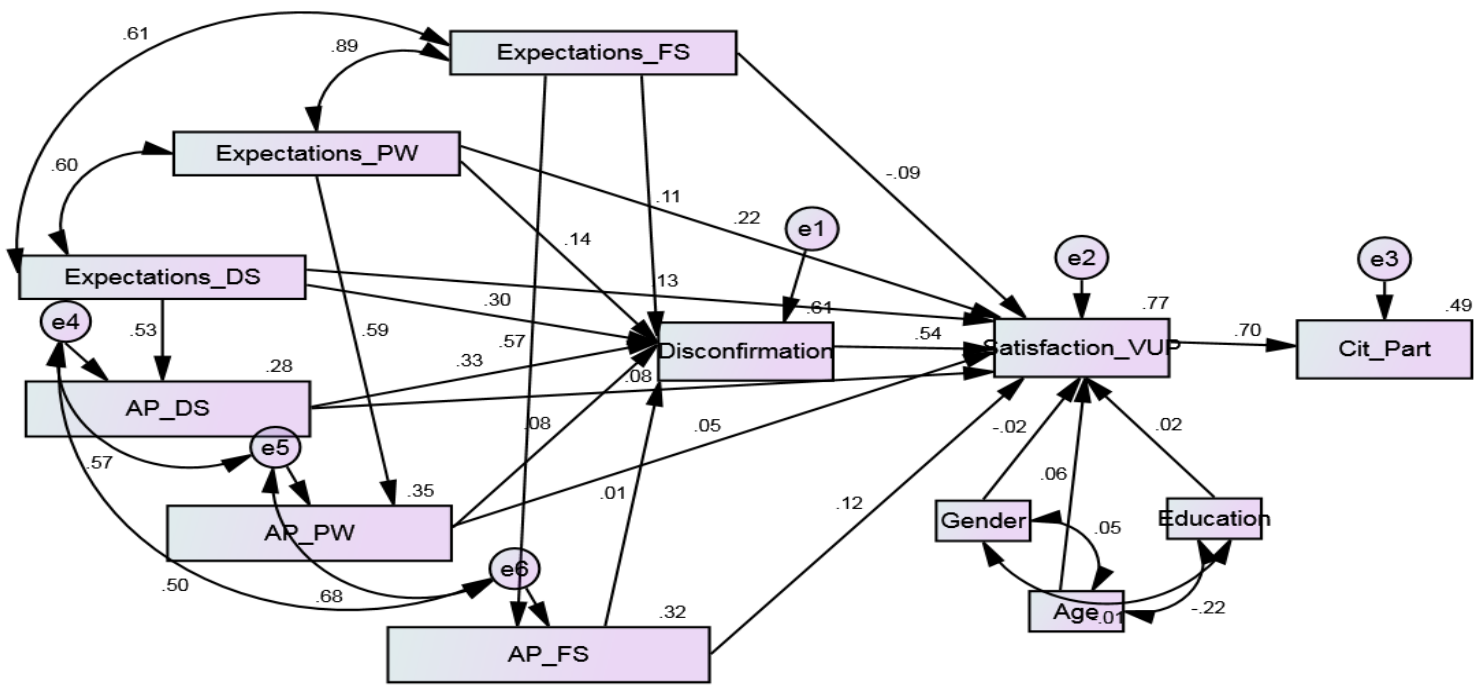

\begin{tabular}{lllllll}
\hline Model 1 & CFI & NFI & IFI & TLI & RFI & RMSEA \\
\hline Suggested Cut-off Values & $>.90$ & $>.90$ & $>.90$ & $>.90$ & $>.85$ & $<.08$ \\
SEM results & .95 & .93 & .95 & .89 & .86 & .09 \\
\hline
\end{tabular}


From the above figure, we have extracted the regressions weights from SPSS Amos whereby based on the P-value $>.01$ we have found that 10 out of the 17 relationships testing using expectancy disconfirmation model on how citizen form their satisfaction with different components of Vision
2020 Umurenge Program are significant. In these regression weights, we have used none standardized estimates whereby standardized estimates are on the model. Table 4 gives details about the relationship of each program component to the beneficiaries' satisfaction with it.

Table 4: Regression Weights (Model 1)

\begin{tabular}{lllllll}
\hline Relationship & & & Estimate & S.E. & C.R. & P \\
\hline AP_DS & $<---$ & Expectations_DS & 0.228 & 0.019 & 11.887 & $* * *$ \\
AP_PW & $<---$ & Expectations_PW & 0.262 & 0.021 & 12.489 & $* * *$ \\
AP_FS & $<---$ & Expectations_FS & 0.263 & 0.023 & 11.254 & $* * *$ \\
Disconfirmation & $<---$ & Expectations_DS & 0.287 & 0.057 & 5.071 & $* * *$ \\
Disconfirmation & $<---$ & Expectations_PW & 0.134 & 0.108 & 1.236 & 0.216 \\
Disconfirmation & $<---$ & Expectations_FS & 0.11 & 0.112 & 0.982 & 0.326 \\
Disconfirmation & $<---$ & AP_DS & 0.728 & 0.128 & 5.703 & $* * *$ \\
Disconfirmation & $<---$ & AP_PW & 0.174 & 0.183 & 0.95 & 0.342 \\
Disconfirmation & $<---$ & AP_FS & 0.013 & 0.167 & 0.077 & 0.939 \\
Satisfaction_VUP & $<---$ & Disconfirmation & 0.518 & 0.042 & 12.345 & $* * *$ \\
Satisfaction_VUP & $<---$ & AP_DS & 0.156 & 0.1 & 1.566 & 0.117 \\
Satisfaction_VUP & $<---$ & AP_PW & 0.099 & 0.133 & 0.748 & 0.454 \\
Satisfaction_VUP & $<---$ & AP_FS & 0.234 & 0.12 & 1.941 & 0.052 \\
Satisfaction_VUP & $<---$ & Expectations_DS & 0.116 & 0.044 & 2.652 & 0.008 \\
Satisfaction_VUP & $<---$ & Expectations_PW & 0.193 & 0.079 & 2.448 & 0.014 \\
Satisfaction_VUP & $<---$ & Expectations_FS & -0.079 & 0.082 & -0.968 & 0.333 \\
Cit_Part & $<---$ & Satisfaction_VUP & 0.37 & 0.019 & 19.007 & $* * *$ \\
\hline
\end{tabular}

As discussed above we have used two models in order to run the data of this survey in SPSS AMOS 21 whereby model 2 which is used to test the hypotheses of the survey based on the structural equation model in AMOS. The second model which was used to test hypotheses is almost similar to the expectancy disconfirmation model except that we have added citizen participation as the dependent variable. In other words, the items used in the survey were transformed using SPSS so as to have variables similar to the ones in EDM. The SEM results (model 2) show that Expectations from the VUP has a positive influence on Performance VUP (coefficient $=.65)$; Expectations from the VUP has a positive influence on Disconfirmation (coefficient $=.42$ ); Performance from the VUP has a positive influence on Disconfirmation (coefficient $=.41$ ); Expectations from the VUP has a positive influence on Satisfaction with VUP (coefficient $=.21$ ); Performance of the VUP has a positive e influence on Satisfaction with VUP (coefficient $=.21$ ); Disconfirmation has a positive influence on Satisfaction with VUP (coefficient $=.54$ ), Satisfaction with VUP ( using EDM) has a positive influence on Citizen Participation (coefficient $=.7$ ). These findings are similar to the ones in the previous researches except the relationship between expectations and disconfirmation whereby previous 
researchers have shown a negative relationship but in the current survey the relationship was found positive. Figure 3 displays the results of the SEM model 2 and it is the one which was used to test the hypothesis.

Figure 3: Vision 2020 Umurenge Program Expectancy-Disconfirmation model with Citizen Participation (Model 2)

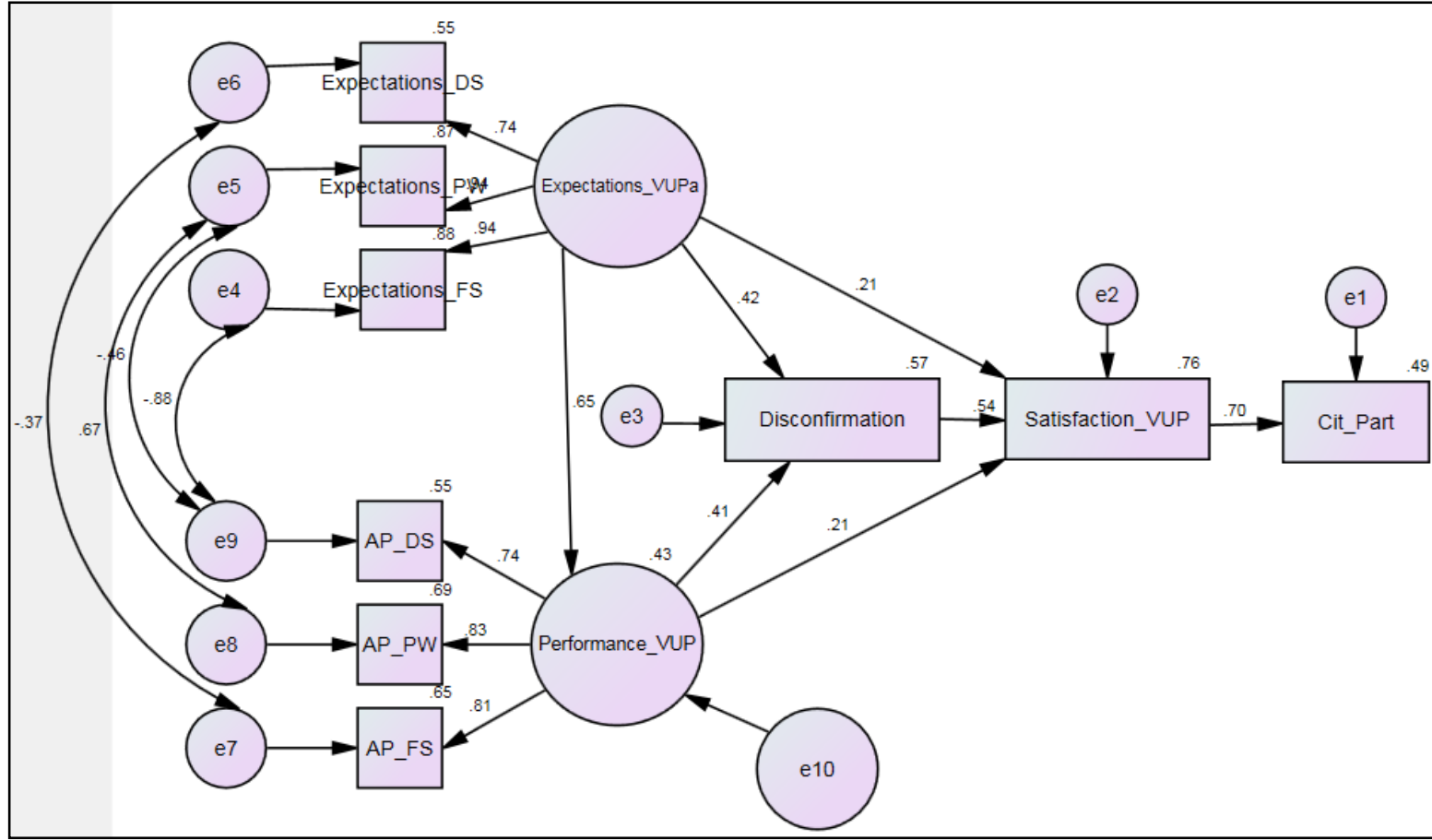

\begin{tabular}{lllllll}
\hline Model 2 & CFI & NFI & IFI & TLI & RFI & RMSEA \\
\hline Cut-off Values & $>.90$ & $>.90$ & $>.90$ & $>.90$ & $>.85$ & $<.08$ \\
SEM results & .92 & .93 & .93 & .94 & .86 & .09
\end{tabular}

From the above figure, we extracted the regressions weights from SPSS Amos whereby based on the Pvalue $>.01$ we have found that all the 7 relationships tested using expectancy disconfirmation model on how citizen form their satisfaction with different components of Vision 2020 Umurenge Program were significant. However, the relationship between expectations from VUP and the disconfirmation of these expectations has shown a positive coefficient while in the previous studies this relationship was found to be negative (Van Ryzin, 2005). In these regression weights, we have used none standardized estimates whereby standardized estimates are on the model. Table 5 gives the details about the relationship of each program component to the beneficiaries' satisfaction with it.

Table 5: Regression Weights: (Model 2)

\begin{tabular}{lllllll}
\hline & & & Stand. Estimate & S.E. & C.R. & P \\
\hline Performance_VUP & $<---$ & Expectations_VUP & 0.65 & 0.03 & 9.67 & $* * *$ \\
Disconfirmation & $<--$ & Expectations_VUP & 0.42 & 0.06 & 6.7 & $* * *$
\end{tabular}




\begin{tabular}{lllllll}
\hline & & & Stand. Estimate & S.E. & C.R. & P \\
\hline Disconfirmation & $<---$ & Performance_VUP & 0.41 & 0.18 & 6.01 & $* * *$ \\
Satisfaction_VUP & $<---$ & Disconfirmation & 0.54 & 0.04 & 12.13 & $* * *$ \\
Satisfaction_VUP & $<---$ & Performance_VUP & 0.21 & 0.13 & 3.94 & $* * *$ \\
Satisfaction_VUP & $<---$ & Expectations_VUP & 0.21 & 0.05 & 4.48 & $* * *$ \\
Cit_Part & $<---$ & Satisfaction_VUP & 0.7 & 0.02 & 18.95 & $* * *$ \\
\hline
\end{tabular}

\section{DISCUSSION AND CONCLUSION}

Model 2 was used to test the hypotheses of the survey based on the structural equation model in AMOS. Testing on the model fit, the results (model 2) shows that the model fit indices and suggested thresholds were satisfied which include NFI $=.93$ ( $>90$ is acceptable), IFI $=.93(>.90$ is acceptable), $\mathrm{TLI}=.94(>.90$ is acceptable $), \mathrm{CFI}=.92(>.90$ is acceptable), RMSEA $=.09$ (<.08 is acceptable), and $\mathrm{RFI}=.86(>85$ is acceptable). The second model which was used to test hypotheses is almost similar to the expectancy disconfirmation model except that we have added citizen participation as the dependent variable. The results of the hypothesis test show that H1, 3, 4, 5, 6 \& 7 were supported because the $\mathrm{P}$ values from SEM were found significant. The coefficients were positive as the hypotheses were suggesting a positive relationship and the model fitness was measured and found fitting, however. H 2 was not supported because even though the P-Value was significant but the coefficient was positive while the hypothesis its self was suggesting the relationship to be negative.

The two major findings from this survey are that (1) it was found that there a positive disconfirmation of the expectations from Vision 2020 Umurenge Program whereby the actual performance of the program was found to be bigger than the expectation from the program; however, the there was no big difference between expectations and actual performance. Secondly, the expectancy disconfirmation model of citizen satisfaction with vision 2020 Umurenge program was found positively and significantly affecting citizen participation. These two big findings can be details by explaining the relationships and significance found between all components of EDM in the following paragraphs.

The findings show that expectations from VUP are positively and significantly affect the actual performance of the program and this has supported our proposed hypothesis concerning the relationship between the two. The expectations from VUP are positively and significantly affecting the perceived disconfirmation from these expectations. However, this relationship was not supporting our survey hypothesis concerning the relationship between the two because of the previous studies (Van Ryzin 2005; 2009), this relationship was to be negative. The actual performance of Vision 2020 was found positively and significantly affecting the perceived disconfirmations supporting our study hypothesis concerning the relationship between actual performance and disconfirmations. The expectations from the Vision 2020 Umurenge Program were found positively and significantly affect the citizen satisfaction with the program, this supported the hypothesis testing relationship between the two. The findings confirm the successful use of EDM in testing the way people form their satisfaction, so it can be used for different programs implemented in the local government of Rwanda. EDM of satisfaction with VUP affects positively and significantly the citizen participation

Policy practitioners have to pay attention to feedback from the citizens. Following best 
practices employed by some local governments who have chosen to focus on citizen feedback and by using EDM to measure citizen satisfaction. EDM can be adopted by policymakers in Rwanda as a way to investigate citizen satisfaction with different programs. Thinking about the relationship between other policies or programs to citizen participation and put other considerable efforts to effectively and efficiently implement of VUP to increase the level of citizen participation. This study makes policy contributions by identifying how citizen form their satisfaction with the Vision 2020 Umurenge program and its relationship with citizen participation this may help policymakers to make policies thinking on how these policies will affect the people's satisfaction.

It was found that there is a positive disconfirmation of the expectations from VUP whereby the actual performance of the program was found to be bigger than the expectation from the program however the there was no big difference between expectations and actual performance. The expectancy disconfirmation model of citizen satisfaction with VUP was found positively and significantly affecting citizen participation. Among the gaps of this survey is that it has tested on the program implemented in the local government of Rwanda which is VUP. Future studies can examine whether differences in factors that influence the adoption of EDM by government institutions and individuals in measuring citizen satisfaction. Significant differences may offer thorough insights into the determinants of citizen satisfaction measurements.

\section{REFERENCES}

Amenta, E., Caren, N., \& Stobaugh, J. E. (2012). Political reform and the historical trajectories of US social movements in the twentieth century. Social Forces, 90(4), 1073-1100.

Barkan, E. R. (Ed.). (2013). Immigrants in American history: Arrival, adaptation, and integration (Vol. 1). Santa Barbara, Calif: ABC-CLIO.
Campbell, A. (1981). The sense of well-being in America: Recent patterns and trends. New York: McGraw-Hill.

DiClemente, R. J., Crosby, R. A., \& Kegler, M. C. (Eds.). (2009). Emerging theories in health promotion practice and research. John Wiley $\&$ Sons.

Erevelles, S., \& Leavitt, C. (1992). A comparison of current models of consumer satisfaction/dissatisfaction. Journal of consumer satisfaction, dissatisfaction, and complaining behaviour, 5(10), 104-114.

Greasley, S., \& John, P. (2011). Does stronger political leadership have a performance payoff? Citizen satisfaction in the reform of subcentral governments in England. Journal of Public Administration Research and Theory, 21(2), 239-256.

Henríquez-Coronel, P., Bravo-Loor, J., DíazBarrera, E., \& Vélez-Romero, Y. (2018, January). Open Government and Citizen Participation in the Web Portals of Ecuador GADM. In International Conference on Information Theoretic Security (pp. 11461155). Springer, Cham.

LODA. (2016). Vision Umurenge 2020 Programme $(V U P):$ accelerating sustainable graduation from extreme poverty and fostering inclusive national development. Kigali-Rwanda: Local Development Agency

McGarry, A. (2017). Romaphobia: the last acceptable form of racism. Zed Books Ltd.

Morgan, L. S. (2013). Handbook of Causal Analysis for Social Research. Ithaca: Springer

Oliver, R. L. (1980). A cognitive model of the antecedents and consequences of satisfaction decisions. Journal of marketing research, 17(4), 460-469. 
Oliver, R. L. (1997). Satisfaction: a behavioural perspective on the consumer. New York: Irwin McGraw-Hill.

Ongaro, E., Massey, A., Holzer, M., \& Wayenberg, E. (Eds.). (2011). Policy, Performance, and Management in Governance and Intergovernmental Relations. Edward Elgar Publishing.

Pitkin, H. F. (1999). Fortune Is a Woman: Gender and Politics in the Thought of Niccolo Machiavelli. Chicago: University of Chicago Press.

Protik, A. E., Nichols-Barrer, I., Berman, J., \& Sloan, M. (2018). Bridging the information gap between citizens and local governments: Evidence from civic participation strengthening program in Rwanda. World Development, 108, 145-156.

Putnam, R. (2000). Bowling along: the collapse and revival of American community. New York: Simon and Schuster.

RGB. (2013). The Rwanda Citizen Report Card 2013 - Citizen Voice on service delivery. Kigali: Rwanda Governance Board.

RGB. (2016). The Rwanda Citizen Report Card 2016 - Citizen Voice on service delivery. Kigali: Rwanda Governance Board.

Scheier, M. F., \& Carver, C. S. (1985). Optimism, coping, and health: assessment and implications of generalized outcome expectancies. Health psychology, 4(3), 219.

Van Ryzin, G. G. (2004). Expectations, performance, and citizen satisfaction with urban services. Journal of policy analysis and management, 23(3), 433-448.

Van Ryzin, G. G. (2005). Testing the expectancy disconfirmation model of citizen satisfaction with local government. Journal of Public
Administration Research and Theory, 16(4), 599-611.

Van Ryzin, G. G. (2013). An experimental test of the expectancy-disconfirmation theory of citizen satisfaction. Journal of Policy Analysis and Management, 32(3), 597-614.

Van Ryzin, G. G., Muzzio, D., Immerwahr, S., Gulick, L., \& Martinez, E. (2004). Drivers and consequences of citizen satisfaction: An application of the American customer satisfaction index model to New York City. Public Administration Review, 64(3), 331-341.

Wu, W. N., \& Jung, K. (2016). A missing link between citizen participation, satisfaction, and public performance: evidence from the city and county of San Francisco. International Journal of Public Sector Performance Management, 2(4), 392-410. 